\title{
An Assessment of Drawing Age in Pre-School Children Using 'Draw-A-Man' Test
}

\author{
Raja $S^{1}$, John BM ${ }^{2}$
}

\begin{abstract}
Introduction: Goodenough-Harris 'Draw-a-Man' Test has been traditionally used as a simple tool to measure mental development in a child. There have very few studies looking at utility of 'Draw a man' test in the Indian subcontinent in the recent past. We carried out an assessment of correlation of drawing age with chronological age in pre-school children by the 'Draw- a- man test' and looked for any associations with respect to a deviation (delay or advancement) in the calculated drawing age. Materials and Methods: A cross-sectional descriptive study was conducted on 100 neurologically normal pre-school children between 36 to 72 months. The data was then analyzed with Pearson correlation and Chi square test on SPSS version 14.0 Result: There was a low positive correlation between drawing age and chronological age (Pearson correlation: $r=+0.31, p=0.002)$. There were more boys $(p=0.004)$ and more children with prematurity $(p=0.012)$ in the group with low or equal drawing age compared to chronological age. Conclusion: In view of the low positive correlation found in our study, further studies with a larger sample need to be conducted to establish the 'Draw-a-man' test as a screening tool for mental age assessment in our subcontinent. We did find a significant association of deviation of drawing age from chronological age with respect to gender and prematurity.
\end{abstract}

Key words: Goodenough-Harris 'Draw a man' test, drawing age, chronological age, pre-school children

\section{Introduction}

G oodenough-Harris 'Draw-a-Man' test has been used as a simple tool to measure mental development. It is a drawing test that gives information about the general aptitude level of young children. This is based on the fact that the nature and content of children's drawings are dependent primarily upon intellectual development. In the drawings of young children, a close relationship exists between concept development and general intelligence. Drawing is a form of expression and a child draws what he knows. The child exaggerates the size of objects which seem interesting or important and marked sex differences, usually in favor of the girls, are frequently observed. The drawing tests have been used since its conception by Florence $L$ Goodenough early in the $20^{\text {th }}$ century for a variety of evaluation such
'Santhosh Raja, $3^{\text {rd }}$ Year MBBS Student, ${ }^{2}$ Dr. BM John, MBBS, MD, Associate Professor. From the Department of Paediatrics, Armed Forces Medical College, Pune, Maharastra, India.

\author{
Address for correspondence \\ Dr. BM John \\ Department of Paediatrics, \\ Armed Forces Medical College, \\ Pune, Maharastra, India. \\ Tel: 00919372326660 \\ E-mail:drbmj1972@yahoo.com
}

\section{How to cite}

Raja S, John BM. An Assessment of Drawing Age in Pre-School Children Using 'Draw-A-Man' Test. J Nepal Paediatr Soc 2014;34(1):14-17.

doi: http://dx.doi.org/10.3126/jnps.v34i1.9299

This work is licensed under a Creative Commons Attribution 3.0 License.

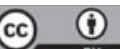

as those of personality, sensory deviates, intellectual development and learning differences ${ }^{1,2,3,4,5,6}$. Today, the children are exposed to a variety of environments against a backdrop of varying genotypic influences. Factors which may influence the cognitive functions include socio-economic status, parental education level, early preschool or play school influence, influence of television, birth order etc. The various environmental influences may advance or retard the age interpretation by this test. There have been very few studies looking at either the correlation of drawing or 
mental age assessed by Goodenough-Harris 'draw a man' test with chronological age in children from Indian subcontinent in the current context or a study aiming to look at any associations for a delay or advancement of age. With this background, the study was conceived to assess the utility of this simple and innovative test to assess mental age and also to look for any specific associations with respect to mismatch between the actual chronological age and age assessed by the 'Draw- a-Man' test.

\section{Materials and Methods}

A cross-sectional descriptive study was conducted in a medical college and hospital in western India over a two month period to look at the correlation of age assessed by the Goodenough 'Draw-a-man' test and actual chronological age in neurologically normal pre-school children and to find any associations towards the reasons for their deviance from normal. We assumed that the Draw-a-man' test would give a reasonably good estimate of the mental age. A sample of 100 children between 36 and 72 months were taken (sample size based on the primary objective of assessment of correlation, taking a possible correlation coefficient of $0.5, \alpha=0.05$ and power of 0.8 ). The children were recruited into the study from immunization clinics, OPD and one pre- nursery school. Information with respect to the demographic profile and other study variables were collected using a pre-designed performa and mental age evaluated by the 'Draw-a-man' test. The data was analysed using appropriate statistical tests with the help of SPSS version 14.0 .

\section{Results}

The study population consisted of 100 children who were taken from the immunization clinic, OPD and one pre-nursery school. The profile of children studied is depicted in Table 1.The Male: Female ratio was $1.78: 1$. $94 \%$ children were of the birth order 1 or $2.85 \%$ children were born term. Only few (15\%) had no outdoor play. $55 \%$ children had more than 1 hour of TV viewing. 84\% children were going to formal schools. $91 \%$ of children had educated parents and $51 \%$ children belonged to upper middle socio-economic status.

The mean (SD, 95\% Cl) of the chronological age and drawing age in months were 58.95(7.34, 57.49-60.41) and 58.76 (10.39, 56.68-60.84) which showed no significant difference. In a comparison of drawing age with chronological age in the children, there were $50 \%$ who had equal or low age and $50 \%$ who had higher mental age compared to the chronological age. There was a low positive correlation between drawing age and chronological age.The $r$ value (Pearson correlation coefficient) was $+0.31(p=0.002)$.

The association of drawing age with various factors is depicted in Table 2. The association of drawing age (advanced or delayed) with sex showed that the percentage of children with advanced drawing age was more in case of girls than in boys with a significant $p$ value (0.004). Drawing age was low in most of the children born preterm when compared to term $(p=0.012)$. Comparison for outdoor play showed that children who did not have outdoor play had more likelihood of low drawing age ( $66 \%$ children who did not play had equal or low drawing ages). However, it was not statistically significant. Comparison for parental education also showed that children who had un-educated parents had a risk of equal or low drawing age $(66 \%$ children who had uneducated parents had equal or low drawing age) but this too was not statistically significant.

Table 1: Characteristics of the study population

\begin{tabular}{|c|c|c|}
\hline Characteristics & Variable & Total \\
\hline \multirow{2}{*}{ Sex } & Male & 64 \\
\hline & Female & 36 \\
\hline \multirow{4}{*}{ Birth order } & 1 & 50 \\
\hline & 2 & 44 \\
\hline & 3 & 4 \\
\hline & 4 & 2 \\
\hline \multirow{2}{*}{ Preterm/term } & Preterm & 15 \\
\hline & Term & 85 \\
\hline \multirow{2}{*}{ Outdoor play } & Yes & 85 \\
\hline & No & 15 \\
\hline \multirow{7}{*}{$\begin{array}{l}\text { TV viewing in } \\
\text { hrs/day }\end{array}$} & 0 & 8 \\
\hline & 0.5 & 8 \\
\hline & 1 & 29 \\
\hline & 2 & 38 \\
\hline & 3 & 11 \\
\hline & 4 & 5 \\
\hline & 5 & 1 \\
\hline \multirow{5}{*}{ Child's education } & No education & 16 \\
\hline & Nursery & 3 \\
\hline & L.K.G & 3 \\
\hline & U.K.G & 74 \\
\hline & $1^{\text {st }}$ STD & 4 \\
\hline \multirow{5}{*}{ Parent's education } & No education & 9 \\
\hline & Upto $10^{\text {th }}$ & 31 \\
\hline & Upto 12th & 30 \\
\hline & Graduate & 26 \\
\hline & Postgraduate & 4 \\
\hline \multirow{4}{*}{$\begin{array}{l}\text { Socio economic } \\
\text { Status } \\
\text { (Kuppuswamy scale) }\end{array}$} & Upper lower & 29 \\
\hline & Lower middle & 8 \\
\hline & Upper middle & 51 \\
\hline & Upper & 12 \\
\hline
\end{tabular}


Table 2: Factors associated with mismatch between chronological age and drawing age

\begin{tabular}{|c|c|c|c|c|c|c|}
\hline Factor & Variable & $\begin{array}{c}\text { High } \\
\text { drawing age }\end{array}$ & $\begin{array}{l}\text { Equal/low } \\
\text { drawing age }\end{array}$ & Total & Chi-square & $p$-value \\
\hline \multirow{2}{*}{ Sex } & Male & 25 & 39 & 64 & \multirow{2}{*}{8.5} & \multirow{2}{*}{0.004} \\
\hline & Female & 25 & 11 & 36 & & \\
\hline \multirow{4}{*}{ Birth order } & 1 & 25 & 25 & 50 & \multirow{4}{*}{0.0} & \multirow{4}{*}{1} \\
\hline & 2 & 22 & 22 & 44 & & \\
\hline & 3 & 2 & 2 & 4 & & \\
\hline & 4 & 1 & 1 & 2 & & \\
\hline \multirow{2}{*}{ Preterm/term } & Preterm & 3 & 12 & 15 & \multirow{2}{*}{6.353} & \multirow{2}{*}{0.012} \\
\hline & Term & 47 & 38 & 85 & & \\
\hline \multirow{2}{*}{ Outdoor play } & Yes & 45 & 40 & 85 & \multirow{2}{*}{1.96} & \multirow{2}{*}{0.161} \\
\hline & No & 5 & 10 & 15 & & \\
\hline \multirow{7}{*}{$\begin{array}{l}\text { TV viewing in } \\
\text { hrs/day }\end{array}$} & 0 & 6 & 2 & 8 & \multirow{7}{*}{7.10} & \multirow{7}{*}{0.312} \\
\hline & 0.5 & 2 & 6 & 8 & & \\
\hline & 1 & 17 & 12 & 29 & & \\
\hline & 2 & 16 & 22 & 38 & & \\
\hline & 3 & 6 & 5 & 11 & & \\
\hline & 4 & 2 & 3 & 5 & & \\
\hline & 5 & 1 & 0 & 1 & & \\
\hline \multirow{5}{*}{$\begin{array}{l}\text { Child's } \\
\text { education }\end{array}$} & No education & 8 & 8 & 16 & \multirow{5}{*}{4.33} & \multirow{5}{*}{0.363} \\
\hline & Nursery & 2 & 1 & 3 & & \\
\hline & L.K.G & 0 & 3 & 3 & & \\
\hline & U.K.G & 37 & 37 & 74 & & \\
\hline & $1^{\text {st }}$ STD & 3 & 1 & 4 & & \\
\hline \multirow{5}{*}{$\begin{array}{l}\text { Parent's } \\
\text { education }\end{array}$} & No education & 3 & 6 & 9 & \multirow{5}{*}{13.67} & \multirow{5}{*}{0.134} \\
\hline & Upto $10^{\text {th }}$ & 17 & 14 & 31 & & \\
\hline & Upto $12^{\text {th }}$ & 16 & 14 & 30 & & \\
\hline & Graduate & 14 & 12 & 26 & & \\
\hline & P.G. & 0 & 4 & 4 & & \\
\hline \multirow{4}{*}{$\begin{array}{c}\text { Socio economic } \\
\text { status }\end{array}$} & Upper lower & 14 & 15 & 29 & \multirow{4}{*}{3.32} & \multirow{4}{*}{0.344} \\
\hline & Lower middle & 2 & 6 & 8 & & \\
\hline & Upper middle & 29 & 22 & 51 & & \\
\hline & Upper & 5 & 7 & 12 & & \\
\hline
\end{tabular}

\section{Discussion}

Goodenough 'Draw-a-Man' test has been traditionally used as a simple tool to measure mental development ${ }^{1-6}$. There have been studies which showed good correlation between mental age assessed by 'draw a man' test with tests of IQ such as Stanford-Binet test with correlations ranging from 0.45 to $0.72^{7,8,9,10}$. Hence we presumed that the 'draw-a -man' test could give us a good estimate of the mental age. With this assumption we wanted to assess the correlation of mental age with chronological age and see whether there were any significant associations between selected variables with respect to a deviation in mental age in today's context in our country.

Our study population consisted of 100 children between the age group of 36-72 months. There were more male children in our study ( $M: F=1.78: 1)$. We had fewer children who had 'no education' (16\%) as opposed to children with 'some form of education' (84\%). We had less number of children in the group whose parents were uneducated or belonged to poor socio-economic strata. This distribution of sample population could have affected our results. In our study, there was a low positive correlation between 
drawing age and chronological age $(r=+0.31, p=0.002)$ though there was no significant difference between the mean chronological age and drawing age. Fifty percent children had advanced drawing age and $50 \%$ had equal or low age compared to the chronological age. This could have been because of any of the factors mentioned in Table 2. In a similar study by Basgul et al, 75 out of 175 (42.85\%) children had same or high drawing age and 100 out of 175 (57.14\%) had low drawing age ${ }^{11}$. In their study, low birth weight and lack of formal schooling was associated with lower drawing age. In our study, there were more boys $(p=0.004)$ and more children with prematurity $(p=0.012)$ in the group with low or equal drawing age compared to chronological age.There was also a statistically insignificant association of the low or equal drawing age with lack of outdoor play(66\% Vs $33 \%, p=0.161)$ and absence of parental education $(66 \%$ Vs 33\%, $p=0.134)$. Birth order, TV viewing, child's education and parent's socio-economic status did not have a statistically significant association with mismatch in drawing age and chronological age. Our study showed a low positive correlation between drawing age and chronological age and we found a significant mismatch between the two ages with respect to prematurity and gender. An important limitation of our study was that we assumed that the 'Draw-a-man' test would correlate reliably with the mental age. This need not have been correct and could have been addressed if we had carried out a formal mental age assessment of the children as part of the study. However, this was not possible due to the nature of the study.

\section{Conclusion}

This study showed a low positive correlation between drawing age and chronological age and we found a significant mismatch between the two ages with respect to prematurity and gender. We suggest larger studies evaluating the relationship between drawing age assessed by the 'Draw-a-man' test, mental age assessed by formal psychological assessment and chronological age and analyzing factors responsible for the deviation in the various ages, to validate our findings and establish the role of Goodenough-Harris 'Draw-a-man' test.
Acknowledgements: Nil

Funding: None

Conflict of Interest: None

Permission from IRB: Yes

\section{References}

1. Harris DB. Children's drawings as measures of intellectual maturity. A revision and extension of the Goodenough Draw-A-Man Test. New York: Harcourt, Brace, and World; 1963.

2. Malchiodi CA. Understanding children's drawings. New York: The Guilford Press;1998.

3. Matto HC. Investigating the validity of the DrawA-Person screening procedure for emotional disturbance. Psychol Assess 2002;14:221-25.

4. Stefanatou A. Use of drawings in children with pervasive developmental disorder during hospitalization: A developmental perspective. J Child Health Care 2008;12:268-83.

5. Barett MD,Light PH. Symbolism and intellectual realism in children's drawings. Brit J Edu Psychol 1976;46:198-202.

6. Goodenough FL. Harris DB. Studies in the psychology of children's drawings. Psychol Bull 1950; 47:369-433.

7. McHugh G. Relationship between Goodenough Draw a man test and the 1937 revision of the Stanford-Binet test. J Edu Psychol 1945; 36(2):11924.

8. Williams JH. Validity and reliability of the Goodenough intelligence test. Sch \& Soc 1935; 67:533-38.

9. Yepsen LN. The reliability of Goodenough drawing test with feeble minded subjects. J Edu Psychol 1929;20:448-51.

10. McElwee EW. The reliability of Goodenough intelligence test used with subnormal children fourteen years of age. J Applied Psychol 1932;16:217-18.

11. Basgul SS, Uneri OS, Akkaya GB, Etiler N, Coskun A. Assessment of Drawing Age of Children in Early Childhood and Its Correlates. Psychology 2011;2(4):376-81. 